\title{
Diversity and community ecology of metazoan parasites in Pimelodus ornatus (Siluriformes: Pimelodidae) from the Amazonas River in Brazil
}

\author{
Diversidade e ecologia da comunidade de parasitos metazoários em \\ Pimelodus ornatus (Siluriformes: Pimelodidae) do Rio Amazonas no Brasil \\ Elvis Silva Lima1,2* (1); Marcos Sidney Brito Oliveira ${ }^{3}$ (1); Marcos Tavares-Dias $1,3,4$ (i] \\ 1 Programa de Pós-graduação em Biodiversidade e Biotecnologia (Rede Bionorte), Universidade Federal do Amapá (UNIFAP), \\ Macapá, AP, Brasil \\ 2 Universidade do Estado do Amapá (UEAP), Macapá, AP, Brasil \\ ${ }^{3}$ Programa de Pós-Graduação em Biodiversidade Tropical (PPGBio), Universidade Federal do Amapá (UNIFAP), Macapá, AP, Brasil \\ ${ }^{4}$ Embrapa Amapá, Macapá, AP, Brasil
}

How to cite: Lima ES, Oliveira MSB, Tavares-Dias M. Diversity and community ecology of metazoan parasites in Pimelodus ornatus (Siluriformes: Pimelodidae) from the Amazonas River in Brazil. Braz J Vet Parasitol 2021; 30(3): e006021. https://doi.org/10.1590/ S1984-29612021065

\begin{abstract}
The present study investigated the metazoan parasite community in Pimelodus ornatus from the Amazon River, in the state of Amapá (Brazil). Of 71 fish examined, 70.4\% were parasitized by Demidospermus sp. (Monogenea), Cucullanus pinnai, Procamallanus (Spirocamallanus) inopinatus and Contracaecum sp. (Nematoda) and plerocercoids from Proteocephalidae gen. sp. (Cestoda). The dominance was of nematode species such as Procamallanus (S.) inopinatus and Contracaecum sp. The parasites showed a highly aggregated dispersion and a predominance of hosts infected by one species of parasite. The parasite community was characterized by a low Shannon diversity index, low evenness and low species richness. The richness of parasite species, Shannon's diversity index, abundance of $P$. (S.) inopinatus and Proteocephalidae gen. sp. showed a positive correlation with the length of the hosts. Therefore, the size of the hosts had an influence on the parasite community and infracommunities, as well as their intermediate position in the food web. This is the first record of $P$. (S.) inopinatus and Contracaecum sp. for $P$. ornatus.
\end{abstract}

Keywords: Aggregation, ectoparasites, endoparasites, freshwater fish, infection.

\begin{abstract}
Resumo
Este estudo investigou a comunidade de parasitos metazoários em Pimelodus ornatus do Rio Amazonas, no estado do Amapá (Brasil). De 71 peixes examinados, 70,4\% estavam parasitados. Um total de 147 parasitos foi coletado, entre Demidospermus sp. (Monogenea), Cucullanus pinnai (Nematoda), Procamallanus (Spirocamallanus) inopinatus e Contracaecum sp. (Nematoda) e plerocercoides de Proteocephalidae gen. sp. (Cestoda). A dominância foi de nematoides como Procamallanus (S.) inopinatus e Contracaecum sp. Os parasitos apresentaram dispersão altamente agregada e predomínio de hospedeiros infectados por uma espécie de parasito. A comunidade de parasitos foi caracterizada por baixo índice de diversidade de Shannon, baixa equitabilidade e baixa riqueza de espécies. A riqueza de espécies de parasitos, índice de diversidade de Shannon, abundância de $P$. (S.) inopinatus e Proteocephalidae gen. sp. apresentaram correlação positiva com o comprimento dos hospedeiros. Portanto, o tamanho dos hospedeiros teve influência sobre a comunidade e infracomunidades de parasitos, bem como sua posição intermediária na cadeia alimentar. Este é o primeiro registro de $P$. (S.) inopinatus e Contracaecum sp. para P. ornatus.
\end{abstract}

Palavras-chave: Agregação, ectoparasitos, endoparasitos, peixes de água doce, infecção.

Received April 1, 2021. Accepted June 18, 2021

*Corresponding author: Elvis Silva Lima. E-mail: elvisbiol10@gmail.com

This is an Open Access article distributed under the terms of the Creative Commons Attribution License, which permits unrestricted use, distribution, and reproduction in any medium, provided the original work is properly cited. 


\section{Introduction}

The Amazon River is the largest drainage basin in the world and accounts for $20 \%$ of the global freshwater, $1.2 \times 10^{9}$ tons of sediment (Nittrouer \& DeMaster, 1986; Milliman, 2001; Chong et al., 2016), 10\% of the dissolved loads and 3\% of the suspended loads that enter the ocean (Milliman \& Syvitski, 1992; Gaillardet et al., 1997; Calvès et al., 2019). In addition, it has a high diversity of fish species.

The diversity of fish in the Amazon River is of economic importance for many riverine populations that live of fishing and use different species of fish for their subsistence (Salo et al., 2013). This diversity is due to the particular characteristics of this large river and its tributaries, which are rich ecosystems with complex trophic chains and with vegetation cover that vary according to the flood regime and regional seasonality (Costa Sousa et al., 2017; Arantes et al., 2019). However, many species of Amazonian fish and their biology are little known (Tavares-Dias \& Oliveira, 2017; Negreiros et al., 2018), such as the Pimelodus ornatus (Kner, 1857).

Pimelodus ornatus is a Pimelodidae, popularly known as mandi-guaru, silver mandi, mandi-pinini or painted mandi. This Siluriformes can be found in the Amazon, Madeira, Parnaíba, Negro, Alto Paraná, Orinoco, which are large rivers in the Guianas, Paraguay, Bolivia, Peru and Venezuela (Nomura, 1984; Torrente et al., 2013; Froese \& Pauly, 2021). Omnivorous fish, active at night, can occur in the main river channels, in rocky bottoms with dead tree trunks, upstream and downstream from rapids and backwaters (Froese \& Pauly, 2021). Their first sexual maturation occurs from $15.4 \mathrm{~cm}$ in length (Vazzoler, 1996) and females can preserve sperm with their secretions by inserting them in the epithelium of their genital tract, being indicative of internal fertilization (Vazzoler, 1996; Boujard, 1997; Le Bail et al., 2000). This host fish has been parasitized by species of Monogenea, Nematoda, Trematoda, Cestoda and Pentastomida (Table 1). However, little is known about the ecological interactions of $P$. ornatus with its parasite community.

Adequate knowledge of parasite biodiversity is crucial for environmental management and conservation initiatives (Poulin, 2004; Negreiros et al., 2019). It is known that among the processes responsible for the spatial distribution of the parasites, they can be related to the constant scenarios of changes in the environment and

Table 1. List of metazoan parasites species reported for Pimelodus ornatus from South. America.

\begin{tabular}{|c|c|c|}
\hline Taxon/parasite species & Locality & References \\
\hline \multicolumn{3}{|l|}{ Monogenea } \\
\hline Demidospermus peruvianus & Peru & Mendoza-Palmero et al. (2019) \\
\hline Demidospermus curvovaginatus & Peru & Mendoza-Palmero et al. (2019) \\
\hline \multicolumn{3}{|l|}{ Nematoda } \\
\hline Cucullanus pinnai & Brazil & Thatcher (2006), Kohn et al. (2011) \\
\hline Pseudocladorchis cylindricus & Brazil & Travassos et al. (1928) \\
\hline \multicolumn{3}{|l|}{ Trematoda } \\
\hline Dadaytrema oxycephala & Brazil & Travassos et al. (1928) \\
\hline Genarchella parva & Argentina & Kohn et al. (2007) \\
\hline Genarchella genarchella & Brazil & Fernandes \& Kohn (2001), Kohn et al. (2011) \\
\hline \multicolumn{3}{|l|}{ Cestoda } \\
\hline Mariauxiella pimelodi & Brazil & De Chambrier \& Rego (1995) \\
\hline Spasskyellina mandi & Brazil & Pavanelli \& Takemoto (1996) \\
\hline Nomimoscolex sp. & Peru & De Chambrier et al. (2015) \\
\hline \multicolumn{3}{|l|}{ Pentastomida } \\
\hline Porocephalus gracilis & Brazil & Travassos et al. (1928) \\
\hline Leiperia gracile & Brazil & Luque et al. (2013) \\
\hline
\end{tabular}


biological invasions, which can lead to diseases (McLeod \& Wing, 2008; Harvell et al., 2009; Altizer et al., 2013). Therefore, biotic and abiotic factors are commonly responsible for the diversity, richness and infection rates by parasites in wild fish (Tavares-Dias et al., 2014; Blasco-Costa et al., 2015; Oliveira et al., 2017; Tavares-Dias \& Oliveira, 2017; Negreiros et al., 2018), affecting the parasite-host relationship. Thus, the objective of the present study was to investigate the diversity and community ecology of metazoan parasites in $P$. ornatus in the Amazon River region of the state of Amapá, northern Brazil.

\section{Materials and Methods}

\section{Sampling area and fish collection}

Seventy-one specimens of $P$. ornatus $(15.8 \pm 2.4 \mathrm{~cm}$ and $18.9 \pm 8.1 \mathrm{~g})$ were collected every two months, from January to September 2020, on the Amazon River near the municipality of Santana, Amapá state (Figure 1). The fish were collected with nets of different sizes and meshes (15, 20, 25, 30 and 35), throw nets (20 mm mesh) and hand lines. The collected specimens were conserved in 10\% formaldehyde and transported to the Embrapa Aquaculture and Fisheries Laboratory, Macapá, Amapá state, Brazil.

During the fish collection, the water quality parameters of electrical conductivity, $\mathrm{pH}$ and total dissolved solids were measured using a multiparameter (COMBO5-02-1016), and the dissolved oxygen and temperature were measured using an oximeter (MO-900). The average water temperature was $29.4 \pm 1.2^{\circ} \mathrm{C}$, dissolved oxygen $5.9 \pm 0.1 \mathrm{mg} / \mathrm{L}, \mathrm{pH} 7.1 \pm 0.2$, total dissolved solids $52.2 \pm 2.0 \mathrm{mg} / \mathrm{L}$ and electrical conductivity $85.8 \pm 4.9 \mu \mathrm{S} / \mathrm{cm}$.

The present study was carried out according to the recommendations and guidelines of the Brazilian College of Animal Experimentation (COBEA) and with authorization from the Ethics Committee on the Use of Animals of Embrapa Amapá (Protocol № 014 - CEUA/CPAFAP).
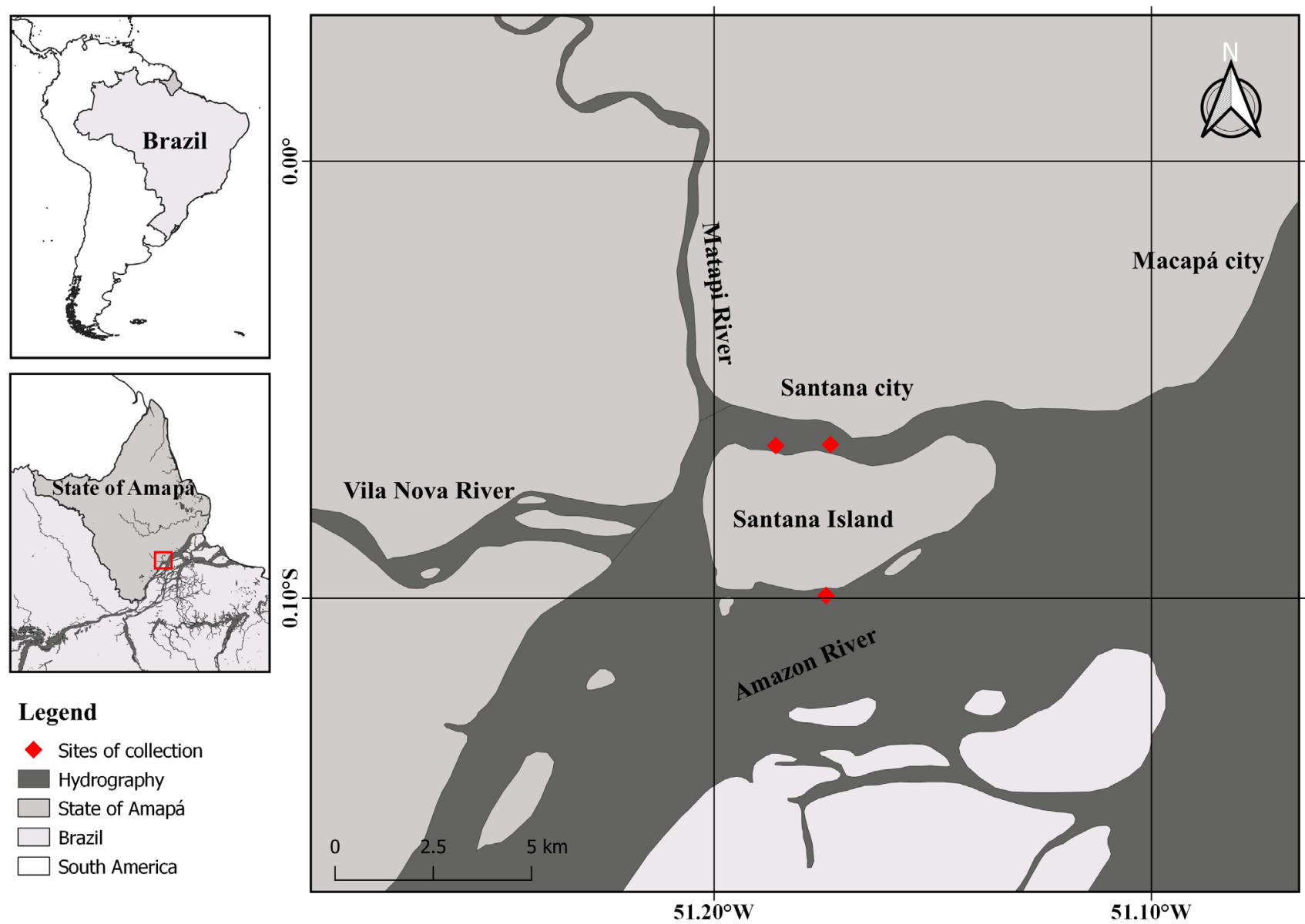

$51.10^{\circ} \mathrm{W}$

Figure 1. Collection site of Pimelodus ornatus in Amazonas River, State of Amapá, northern Brazil. 


\section{Collection and analytical procedures of the parasites}

All fish were weighed $(\mathrm{g})$ and the total length $(\mathrm{cm})$ was measured, and the gills, gastrointestinal tract and viscera were examined for the presence of metazoan parasites. The gills, gastrointestinal tract and viscera were examined with a stereomicroscope and the observed parasites were fixed with $70 \%$ ethyl alcohol. The parasites were prepared for identification using the methodology described in Eiras et al. (2006). Parasites were identified according to Moravec (1998) and Thatcher (2006), and specialized papers. Voucher specimens were deposited at Instituto de Pesquisas Cientificas e Tecnológicas do Estado do Amapá (IEPA), Macapá, AP, Brazil, in the Scientific Collection Curation Office for the Fauna of Amapá, under accession number IEPA:160-164P.

\section{Data analysis}

Prevalence, mean abundance, and mean intensity of parasite infracommunities (Bush et al., 1997) and frequency of dominance (Rohde et al., 1995) were calculated. The dispersion index (ID) and the significance of the ID were calculated using the $d$-statistic with the software Quantitative Parasitology 3.0, as well as the Poulin discrepancy index (D) (Ludwig et al., 1988). These parameters were calculated for species with a prevalence $>10 \%$.

All data were previously evaluated on the assumptions of normality and homoscedasticity using the Shapiro-Wilk and Bartlett tests, respectively. The Shannon index $(H)$, evenness $(E)$ and species richness of parasites (Rohde et al., 1995, Magurran, 2004) were used to estimate parasite diversity. Spearman's correlation coefficient ( $r s$ ) was used to investigate possible correlations between host body length and weight with the richness of parasite species, Shannon index and parasite abundance.

\section{Results}

Pimelodus ornatus specimens were parasitized by Demidospermus Suriano, 1983, Cucullanus pinnai (Travassos, Artigas \& Pereira, 1928); Procamallanus (Spirocamallanus) inopinatus (Travassos, Artigas \& Pereira, 1928), larvae of Contracaecum Railliet \& Henry, 1912 and plerocercoids of Proteocephalidae La Rue, 1911 (Table 2). However, the dominance was of nematode species and no parasites were found in the mouth and operculum of the examined hosts. The parasites showed aggregate dispersion (Table 3).

Table 2. Parasitic helminths in Pimelodus ornatus from Amazonas River, State of Amapá, in Brazil

\begin{tabular}{|c|c|c|c|c|c|c|}
\hline Parasite species & $\mathbf{P}(\%)$ & $\mathrm{MA} \pm \mathrm{SD}$ & $\mathrm{MI} \pm \mathrm{SD}$ & TNP & FD (\%) & SI \\
\hline \multicolumn{7}{|l|}{ Monogenea } \\
\hline Demidospermus sp. & 2.8 & $0.04 \pm 0.3$ & $1.5 \pm 1.0$ & 3 & 2.1 & Gills \\
\hline \multicolumn{7}{|l|}{ Nematoda } \\
\hline Contracaecum sp. (larvae) & 22.5 & $0.4 \pm 1.0$ & $1.9 \pm 1.4$ & 31 & 21.2 & Intestine \\
\hline Contracaecum sp. (larvae) & 2.8 & $0.03 \pm 0.2$ & $1.0 \pm 0$ & 3 & 1.4 & Stomach \\
\hline Procamallanus (S.) inopinatus & 52.1 & $1.2 \pm 1.5$ & $2.4 \pm 1.3$ & 88 & 60.3 & Intestine \\
\hline Procamallanus (S.) inopinatus & 1.4 & $0.01 \pm 0.1$ & $1.0 \pm 0$ & 1 & 0.7 & Stomach \\
\hline Procamallanus (S.) inopinatus & 1.4 & $0.01 \pm 0.1$ & $1.0 \pm 0$ & 1 & 0.7 & Abdominal cavity \\
\hline Cucullanus pinnai & 5.6 & $0.1 \pm 0.2$ & $1.0 \pm 0$ & 4 & 2.7 & Intestine \\
\hline \multicolumn{7}{|l|}{ Cestoda } \\
\hline $\begin{array}{l}\text { Proteocephalidae gen. sp. } \\
\text { (plerocercoids) }\end{array}$ & 11.3 & $0.2 \pm 0.6$ & $1.6 \pm 1.1$ & 13 & 8.9 & Intestine \\
\hline $\begin{array}{l}\text { Proteocephalidae gen. sp. } \\
\text { (plerocercoids) }\end{array}$ & 4.2 & $0.04 \pm 0.2$ & $1.0 \pm 0$ & 3 & 2.0 & Stomach \\
\hline
\end{tabular}

P: Prevalence, MA: Mean abundance, MI: Mean intensity, TNP: Total number of parasites, FD: Frequency of dominance, SI: Site of infection, SD: Standard deviation. 
The parasite component community showed a low Shannon diversity index, low evenness and low species richness, and predominance of endoparasite species (Table 4). There was a predominance of hosts infected by one species of parasite (Figure 2).

Table 3. Index of dispersion (ID), $d$-statistical $(d)$ and discrepancy index (D) of parasite infracommunities in Pimelodus ornatus from the Amazonas River, Amapá state, in Brazil.

\begin{tabular}{ccccc}
\hline Parasite species & ID & $\boldsymbol{d}$ & D & Dispersion type \\
\hline Contracaecum sp. & 2.74 & 5.5 & 0.83 & Aggregated \\
Procamallanus (S.) inopinatus & 1.77 & 4.0 & 0.60 & Aggregated \\
Proteocephalidae gen. sp. & 1.85 & 4.3 & 0.83 & Aggregated \\
\hline
\end{tabular}

Table 4. Component community of metazoan parasites in Pimelodus ornatus from the Amazon River, state of Amapá, in Brazil.

\begin{tabular}{lc}
\multicolumn{1}{c}{ Parameters } & Values \\
\hline All species of parasites & 71 \\
Number of hosts examined & 70.4 \\
Total prevalence (\%) of parasites & 147 \\
Total number of parasites & 5 \\
Number species of parasites & $0.2 \pm 0.3$ \\
Diversity of Shannon & $0.1 \pm 0.2$ \\
Evenness & $1.0 \pm 0.8$ \\
Species richness of parasites & \\
Species of endoparasites & 4 \\
Number species of endoparasites & 97.9 \\
Percentage of endoparasites (\%) & 2 \\
Species of endoparasites (larvae) & 2 \\
Species of endoparasites (adults) & 1 \\
Species of ectoparasites & 1 \\
Number species of ectoparasites & 2.1 \\
Percentage of ectoparasites (\%) & 0 \\
Species of ectoparasites (larvae) & \\
\hline
\end{tabular}

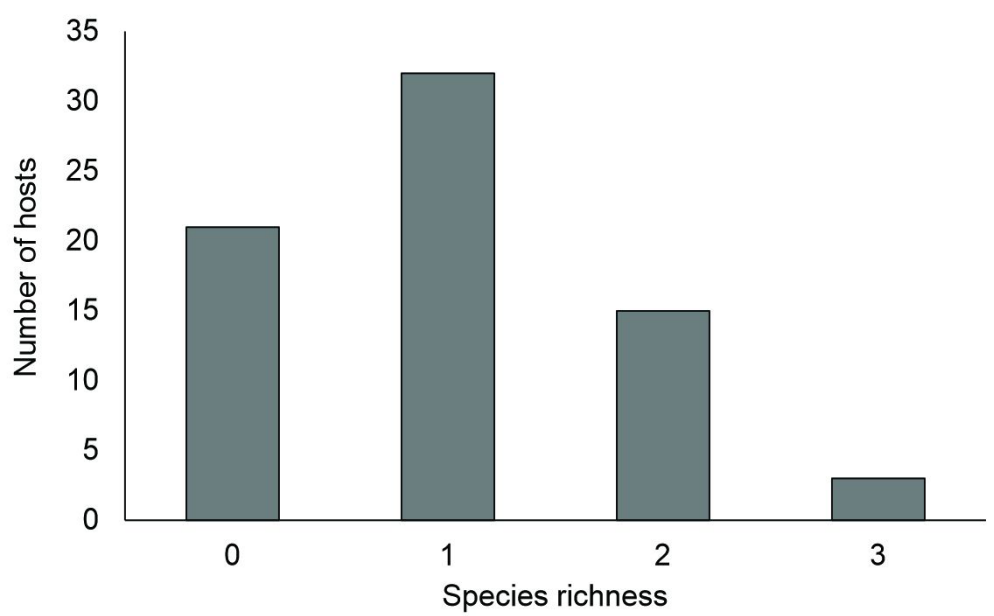

Figure 2. Species richness of metazoan parasites in Pimelodus ornatus from the Amazon River, Amapá of State, in Brazil. 
The species richness of parasites $(r s=0.24 ; p=0.04)$ and Shannon's diversity index $(r s=0.29 ; p=0.01)$ showed a weak positive correlation with the length of the hosts. The richness of parasite species $(r s=0.18, p=0.12)$ had no correlation with the weight of the hosts, but the Shannon's diversity index ( $r s=0.27 ; p=0.02)$ showed weak positive correlation with the weight of the hosts. The abundance of $P$. $(S)$ inopinatus $(r s=0.21 ; p=0.01)$ and Proteocephalidae gen. sp. $(r s=0.22 ; p=0.05)$ showed a weak positive correlation with the length of the hosts. There was no correlation between the weight of the hosts and the abundance of $P$. $(S)$ inopinatus $(r s=0.08 ; p=0.50)$, Proteocephalidae gen. sp. $(r s=0.22 ; p=0.06)$ and Contracaecum sp. $(r s=-0.05 ; p=0.66)$. The abundance Contracaecum sp. $(r s=-0.01$, $\mathrm{p}=0.91)$ there was no correlation between host length.

\section{Discussion}

The component community of metazoan parasites in $P$. ornatus from the Amazon River consisted of one species of Monogenea, three species of Nematoda and one species of Cestoda. Few parasite species known for $P$. ornatus were found here (Table 1). For $P$. ornatus sampled from the reservoir of the Hydroelectric Power Station of Itaipu, State of Paraná (Brazil), Kohn et al. (2011) reported only one Nematoda species and one Digenea species. In contrast, the metazoan community in Pimelodus blochii (Valenciennes 1840) from the Acre and laco rivers, was made up of five species of Monogenea, 10 Nematoda, three Digenea, one Cestoda and three Crustacea (Negreiros et al., 2018); in Pimelodus pohli Ribeiro \& Lucena, 2006 of the São Francisco river, for two species of Monogenea, three Nematoda, one Digenea and one Acanthocephala (Sabas \& Brasil-Sato, 2014) and in Pimelodus maculatus Lacepède, 1803 of the Guandu River for one species of Nematoda and one species of Cestoda (Albuquerque et al., 2008). These results are probably related to omnivorous fed habit of these host fish species (Froese \& Pauly, 2021), considering that acquiring of nematodes and other endoparasites are linked to the diet (Sabas \& Brasil-Sato, 2014; Blasco- Costa et al., 2015; Oliveira et al., 2017; Tavares-Dias \& Oliveira, 2017; Negreiros et al., 2018). However, such differences in the component community and parasite richness may be attributed to the difference in host species, diet and different environments.

In P. ornatus, the parasites showed an aggregate dispersion pattern, which is common in several species of freshwater fish from various natural environments (Sabas \& Brasil-Sato, 2014; Tavares-Dias \& Oliveira, 2017; Oliveira et al., 2019; Neves et al., 2020a). This aggregation may be associated with the genetic variability of the host population, decreased interspecific competition between parasites, decreased damage to the host and other environmental factors (Poulin, 2013; Tavares-Dias \& Oliveira, 2017; Salgado-Maldonado et al., 2019).

Monogeneans are parasites that may serve as indicators of environmental quality, since they are generally present in greater abundance in aquatic environments with low conditions in water (Dogiel, 1961; Oliveira et al., 2017, 2019; Negreiros et al., 2018). In addition, most monogenean parasites are species-specific, parasitizing a host or phylogenetically related hosts. The depth of the water body and flow velocity limit the exploitation of monogenean species in the host fish (Negreiros et al., 2018). In P. ornatus of the Amazon River, an environment with a high average water flow $\left(1.0 \times 10^{5} \mathrm{~m}^{3} / \mathrm{s}\right)$, which prevents the accumulation and permanence of pollutants and eutrophication (Abreu et al., 2020), and with a high level of oxygen, there was a low level of infection by monogeneans Demidospermus sp. Negreiros et al. (2018) reported that anthropogenic development of the Rio Acre influenced the levels of infection by Demidospermus peruvianus Mendoza-Palermo \& Scholz, 2011; Demidospermus striatus Mendoza-Palermo \& Scholz, 2011; Demidospermus sp. and Ameloblastella Kritsky, Mendoza-Franco \& Schoz, 2000 in the gills of $P$. blochii.

In P. ornatus, larval stage of Contracaecum sp. and Proteocephalidae gen. sp. were present, indicating that this fish is an important intermediate host in the transmission of these endoparasites perhaps due to its omnivorous feeding habit (Sánchez-Botero \& Araújo-Lima, 2001; Froese \& Pauly, 2021). We observed that P. ornatus was feeding on small crustaceans such as crabs and shrimp. In addition, P. ornatus also feeds on small fish (Sá-Oliveira et al., 2014). These results indicate that $P$. ornatus occupies a lower position in the food chain, thus facilitating these infections by such endoparasites with different life cycles. However, this was the first record of Contracaecum sp. for P. ornatus.

Procamallanus (S.) inopinatus, a nematode with wide geographic distribution and is found in different species of fish in Brazil (Neves et al. 2020b), was recorded here for the first time in P. ornatus. This endoparasite was the dominant species in $P$. ornatus and had a higher level of infection when compared to Contracaecum sp. and C. pinnai, and occurred in the intestine, stomach and abdominal cavity. However, the levels of $C$. pinnai infection in $P$. ornatus were low when compared to P. blochii from the laco and Acre rivers (Negreiros et al., 2018; Negreiros et al., 2019) 
and P. maculatus from the Rio Guandu (Albuquerque et al., 2008). Cucullanus pinnai has also been reported to parasitize Pimelodus albicans (Valenciennes, 1840) (Chemes \& Takemoto, 2011) and Pimelodus clarias (Linnaeus, 1758) (Kohn \& Fernandes, 1987), demonstrating that this is a common nematode infecting species of Pimelodus.

No crustacean parasite species was found on the gills of $P$. ornatus from the Amazonas River. Similar findings were reported by Neves \& Tavares-Dias (2019) for Ageneiosus ucayalensis (Castelnau, 1855), Pimelodella eigenmanni (Boulenger, 1891), Colomesus asellus (Muller \& Troschel, 1849), Pimelodus blochii (Valenciennes, 1840), P. ornatus, Platynematichthys notatus (Jardine, 1841) and Peckoltia lineola (Armbruster, 2008) from Matapi River, a tributary of the Amazonas River, in Amapá State (Brazil). This absence of parasitic crustacean species may be due to the water velocity and daily tides from the Amazonas River (Abreu et al., 2020), given that these ectoparasites need to swim to find adequate hosts, while others depend on the flow of water and swimming speed (Neves \& Tavares-Dias, 2019).

In $P$. ornatus, regarding the host-parasite relationship, there was a positive correlation of the species richness of parasites and Shannon diversity index with the total length of the host, demonstrating that the size of the fish influenced these parameters. Similar findings have been reported for Chaetobranchopsis orbicularis (Steindachner, 1975) (Tavares-Dias \& Oliveira, 2017), Colossoma macropomum Cuvier, 1816 (Gonçalves et al., 2018) and Acestrorhynchus falcirostris (Cuvier, 1819) (Hoshino et al., 2016). Moreover, the body length of $P$. ornatus also influenced in the abundance of $P$. (S) inopinatus and Proteocephalidae gen. sp., in which larger fish tended showed more parasites when compared to smaller ones, although these correlations explicit only $22 \%$ of occurrence of this parasite. Determining the factors that affect the parasites present in wild fish populations is important for parasite ecology studies. However, in fish populations, the influence of the body size on parasite load may vary, and the causes of variations are little understood.

\section{Conclusions}

The parasite community of $P$. ornatus in the Amazon River was composed of helminth species with low prevalence, low abundance, low diversity and low species richness, predominance of ectoparasites and with aggregate dispersion. The size of the host fish influenced the diversity of parasites, explaining less than $25 \%$ of the occurrence of parasites. In addition, new reports of parasites have been recorded for $P$. ornatus. The data obtained here emphasize the importance of the Amazon River as a source of biodiversity. It was possible to contribute to an increase in the knowledge of the freshwater biodiversity from the Amazon, expanding the ecological interactions of parasites and biological information on this Amazonian siluriform with gaps in the literature. This information may be used for future comparisons in studies on the impacts of anthropogenic actions on the parasitic diversity of $P$. ornatus in the Amazon River.

\section{Acknowledgements}

This study received financial support from the National Council for Scientific and Technological Development (Conselho Nacional de Desenvolvimento Científico e Tecnológico, CNPq) through a productivity grant to TavaresDias, M (Process number 303013/2015-0)

\section{References}

Abreu CHM, Barros MLC, Brito DC, Teixeira MR, Cunha ACDA. Hydrodynamic modeling and simulation of water residence time in the estuary of the lower Amazon River. Water 2020; 12(3): 660. http://dx.doi.org/10.3390/w12030660.

Albuquerque MC, Santos MD, Monteiro CM, Martins AN, Ederli NB, Brasil-Sato MAC. Helmintos endoparasitos de Pimelodus maculatus Lacépède, 1803, (Actinopterygii, Pimelodidae) de duas localidades (lagoa e calha do rio) do Rio Guandu, Estado do Rio de Janeiro, Brasil. Rev Bras Parasito/ Vet 2008; 17(Suppl 1): 113-119. PMid:20059829.

Altizer S, Ostfeld RS, Johnson PT, Kutz S, Harvell CD. Climate change and infectious diseases: from evidence to a predictive framework. Science 2013; 341(6145): 514-519. http://dx.doi.org/10.1126/science.1239401. PMid:23908230.

Arantes CC, Winemiller KO, Petrere M, Freitas CEC. Spatial variation in aquatic food webs in the Amazon River floodplain. Freshw Sci 2019; 38(1): 213-228. http://dx.doi.org/10.1086/701841.

Blasco-Costa I, Rouco C, Poulin R. Biogeography of parasitism in freshwater fish: spatial patterns in hot spots of infection. Ecography 2015; 38(3): 301-310. http://dx.doi.org/10.1111/ecog.01020. 
Boujard T. Poissons de Guyane: Guide écologique de l'Approuague et de la réserve des Nouragues. Paris: Editions Quae; 1997.

Bush AO, Lafferty KD, Lotz JM, Shostak AW. Parasitology meets ecology on its own terms: margolis et al. revisited. J Parasitol 1997; 83(4): 575-583. http://dx.doi.org/10.2307/3284227. PMid:9267395.

Calvès G, Calderon Y, Roso V, Bonnel C, Roddaz M, Brusset S, et al. Past Amazon Basin fluvial systems, insight into the Cenozoic sequences using seismic geomorphology (Marañón Basin, Peru). J S Am Earth Sci 2019; 90: 440-452. http://dx.doi.org/10.1016/j. jsames.2018.12.019.

Chemes SB, Takemoto RM. Diversity of parasites from middle Paraná system freshwater fishes, Argentina. Int J Biodivers Conserv 2011; 3(7): 249-266. http://dx.doi.org/10.5897/JJBC.9000044.

Chong LS, Berelson WM, Hammond DE, Fleisher MQ, Anderson RF, Rollins NE, et al. Biogenic sedimentation and geochemical properties of deep-sea sediments of the demerara slope/abyssal plain: influence of the Amazon River Plume. Mar Geol 2016; 379: 124-139. http://dx.doi.org/10.1016/j.margeo.2016.05.015.

Costa Sousa RG, Souza LA, Frutuoso ME, Freitas CEC. Seasonal dynamic of Amazonian small-scale fisheries is dictated by the hydrologic pulse. Bol Inst Pesca 2017; 43(2): 207-221. http://dx.doi.org/10.20950/1678-2305.2017v43n2p207.

De Chambrier A, Rego AA. Mariauxiella pimelodi n. g., n. sp. (Cestoda: Monticelliidae): a parasite of pimelodid siluroid fishes from South America. Syst Parasitol 1995; 30(1): 57-65. http://dx.doi.org/10.1007/BF00009245.

De Chambrier A, Waeschenbach A, Fisseha M, Scholz T, Mariaux J. A large 28S rDNA-based phylogeny confirms the limitations of established morphological characters for classification of proteocephalidean tapeworms (Platyhelminthes, Cestoda). ZooKeys 2015; 500(500): 25-59. http://dx.doi.org/10.3897/zookeys.500.9360. PMid:25987870.

Dogiel VA. Ecology of the parasites of freshwater fishes. In: Dogel VA, Petrushevski GK, Polyanski YI, editors. Parasitology of fishes. Leningrad: University Press; 1961. p. 1-47.

Eiras JC, Takemoto RM, Pavanelli GC. Métodos de estudos e técnicas laboratóriais em parasitologia de peixes. Maringá: Eduem; 2006. Fernandes BMM, Kohn A. On some trematodes parasites of fishes from Paraná River. Braz J Biol 2001; 61(3): 461-466. http:// dx.doi.org/10.1590/S1519-69842001000300016. PMid:11706574.

Froese R, Pauly D. FishBase. Version (2/2021) [online]. USA: FishBase; 2021 [cited 2020 Feb 5]. Available from: www.fishbase.org Gaillardet J, Dupre B, Allegre CJ, Négrel P. Chemical and physical denudation in the Amazon River Basin. Chem Geol 1997; 142(3): 141-173. http://dx.doi.org/10.1016/S0009-2541(97)00074-0.

Gonçalves BB, Oliveira MSB, Borges WF, Santos GG, Tavares-Dias M. Diversity of metazoan parasites in Colossoma macropomum (Serrasalmidae) from the lower Jari River, a tributary of the Amazonas River in Brazil. Acta Amazon 2018; 48(3): 211-216. http:// dx.doi.org/10.1590/1809-4392201704371.

Harvell D, Altizer S, Cattadori IM, Harrington L, Weil E. Climate change and wildlife diseases: when does the host matter the most? Ecology 2009; 90(4): 912-920. http://dx.doi.org/10.1890/08-0616.1. PMid:19449685.

Hoshino MDFG, Neves LR, Tavares-Dias M. Parasite communities of the predatory fish, Acestrorhynchus falcatus and Acestrorhynchus falcirostris, living in sympatry in Brazilian Amazon. Rev Bras Parasitol Vet 2016; 25(2): 207-216. http://dx.doi.org/10.1590/S198429612016038. PMid:27334822.

Kohn A, Fernandes BM. Estudo comparativo dos helmintos parasitos de peixes do Rio Mogi Guassu, coletados nas excursões realizadas entre 1927 e 1985. Mem Inst Oswaldo Cruz 1987; 82(4): 483-500. http://dx.doi.org/10.1590/S0074-02761987000400006. PMid:3507917.

Kohn A, Fernandes BMM, Cohen SC. South American trematodes parasites of fishes. Rio de Janeiro: Imprinta Express Ltda; 2007.

Kohn A, Moravec F, Cohen SC, Canzi C, Takemoto RM, Fernandes BM. Helminths of freshwater fishes in the reservoir of the Hydroelectric Power Station of Itaipu, Paraná, Brazil. Check List 2011; 7(5): 681-690. http://dx.doi.org/10.15560/7.5.681.

Le Bail PY, Keith P, Planquette P. Atlas des poissons d'eau douce de Guyane. Paris: Muséum National d'Histoire Nattrelle; 2000.

Ludwig JA, Quartet L, Reynolds JF, Reynolds JS. Statistical ecology: a primer in methods and computing. New York: John Wiley \& Sons; 1988.

Luque JL, Vieira F, Takemoto R, Pavanelli G, Eiras J. Checklist of Crustacea parasitizing fishes from Brazil. Check List 2013; 9(6): 1449-1470. http://dx.doi.org/10.15560/9.6.1449.

Magurran A. Measuring biological diversity. Oxford: Blackwell Publishing; 2004.

McLeod RJ, Wing SR. Influence of an altered salinity regime on the population structure of two infaunal bivalve species. Estuar Coast Shelf Sci 2008; 78(3): 529-540. http://dx.doi.org/10.1016/j.ecss.2008.01.019. 
Mendoza-Palmero CA, Mendoza-Franco EF, Acosta AA, Scholz T. Walteriella n. g. (Monogenoidea: Dactylogyridae) from the gills of pimelodid catfishes (Siluriformes: Pimelodidae) from the Peruvian Amazonia based on morphological and molecular data. Syst Parasitol 2019; 96(6): 441-452. http://dx.doi.org/10.1007/s11230-019-09866-8. PMid:31165371.

Milliman JD, Syvitski JPM. Geomorphic/tectonic control of sediment discharge to the ocean: the importance of small mountainous Rivers. J Geol 1992; 100(5): 525-544. http://dx.doi.org/10.1086/629606.

Milliman JD. River inputs. In: Steele JH, Trorpe SA, Turekian KK, editors. Encyclopedia of Ocean Sciences. San Diego: Academic Press; 2001. p. 2419-2427. http://dx.doi.org/10.1006/rwos.2001.0074.

Moravec F. Nematodes of freshwater fishes of the Neotropical Region. Praha: Vydala Academia; 1998.

Negreiros LP, Florentino AC, Pereira FB, Tavares-Dias M. Long-term temporal variation in the parasite community structure of metazoans of Pimelodus blochii (Pimelodidae), a catfish from the Brazilian Amazon. Parasitol Res 2019; 118(12): 3337-3347. http:// dx.doi.org/10.1007/s00436-019-06480-x. PMid:31664517.

Negreiros LP, Pereira FB, Tavares-Dias M, Tavares LER. Community structure of metazoan parasites from Pimelodus blochii in two rivers of the western Brazilian Amazon: same seasonal traits, but different anthropogenic impacts. Parasito/ Res 2018; 117(12): 3791-3798. http://dx.doi.org/10.1007/s00436-018-6082-5. PMid:30221326.

Neves LR, Negreiros LP, Silva LMA, Tavares-Dias M. Diversity of monogenean parasites on gills of fishes from the Matapi River, in the Brazilian Amazon. Rev Bras Parasito/ Vet 2020a; 29(4): e013520. http://dx.doi.org/10.1590/s1984-29612020081. PMid:33053058.

Neves LR, Silva LMA, Florentino AC, Tavares-Dias M. Distribution patterns of Procamallanus (Spirocamallanus) inopinatus (Nematoda: Camallanidae) and its interactions with freshwater fish in Brazil. Rev Bras Parasitol Vet 2020b; 29(4): e012820. http://dx.doi. org/10.1590/s1984-29612020092. PMid:33295383.

Neves LR, Tavares-Dias M. Low levels of crustacean parasite infestation in fish species from the Matapi River in the state of Amapá, Brazil. Rev Bras Parasitol Vet 2019; 28(3): 493-498. http://dx.doi.org/10.1590/s1984-29612019006. PMid:31188939.

Nittrouer CA, DeMaster DJ. Sedimentary processes on the Amazon continental shelf: past, present and future research. Cont Shelf Res 1986; 6(1-2): 5-30. http://dx.doi.org/10.1016/0278-4343(86)90051-8.

Nomura H. Dicionário dos peixes do Brasil. Rio de Janeiro: Technical Books Livraria; 1984.

Oliveira MSB, Adriano EA, Tavares-Dias M, Corrêa LL. Monogenoidea parasites of Cichla monoculus and Cichla pinima (Osteichthyes: Cichlidae), sympatric fish in lower Tapajós River, Northern Brazil. Ann Parasito/ 2019; 65(4): 371-380. http://dx.doi.org/10.17420/ ap6504.223. PMid:32191984.

Oliveira MSB, Gonçalves RA, Ferreira DO, Pinheiro DA, Neves LR, Dias MKR, et al. Metazoan parasite communities of wild Leporinus friderici (Characiformes: Anostomidae) from Amazon River system in Brazil. Stud Neotrop Fauna Environ 2017; 52(2): $146-156$. http://dx.doi.org/10.1080/01650521.2017.1312776.

Pavanelli GC, Takemoto RM. Spasskyellina mandi n. sp. (Proteocephalidea: Monticelliidae), parasite of Pimelodus ornatus Kner, 1857 (Pisces: Pimelodidae) of the Paraná River, Paraná, Brazil. Mem Inst Oswaldo Cruz 1996; 91(6): 723-726. http://dx.doi.org/10.1590/ S0074-02761996000600013. PMid:9283653.

Poulin R. Explaining variability in parasite aggregation levels among host samples. Parasitology 2013; 140(4): 541-546. http:// dx.doi.org/10.1017/S0031182012002053. PMid:23343821.

Poulin R. Macroecological patterns of species richness in parasite assemblages. Basic Appl Ecol 2004; 5(5): 423-434. http://dx.doi. org/10.1016/j.baae.2004.08.003.

Rohde K, Hayward C, Heap M. Aspects of the ecology of metazoan ectoparasites of marine fishes. Int J Parasitol 1995; 25(8): 945-970. http://dx.doi.org/10.1016/0020-7519(95)00015-T. PMid:8550295.

Sabas CSS, Brasil-Sato MC. Helmintofauna de Pimelodus pohli (Actinopterygii: Pimelodidae) do alto Rio São Francisco, Brasil. Rev Bras Parasitol Vet 2014; 23(3): 375-382. http://dx.doi.org/10.1590/S1984-29612014067. PMid:25271459.

Salgado-Maldonado G, Mendoza-Franco EF, Caspeta-Mandujano JM, Ramírez-Martínez C. Aggregation and negative interactions in low-diversity and unsaturated monogenean (Platyhelminthes) communities in Astyanax aeneus (Teleostei) populations in a Neotropical river of Mexico. Int J Parasitol Parasites Wildl 2019; 8: 203-215. http://dx.doi.org/10.1016/j.ijppaw.2019.02.005. PMid:30891400.

Salo M, Sirén A, Kalliola R. Diagnosing wild species harvest: resource use and conservation. New York: Academic Press; 2013. http:// dx.doi.org/10.1016/B978-0-12-397204-0.00020-6.

Sánchez-Botero Jl, Araújo-Lima CARM. As macrófitas aquáticas como berçário para a ictiofauna da várzea do rio Amazonas. Acta Amazon 2001; 31(3): 437-447. http://dx.doi.org/10.1590/1809-43922001313447. 
Sá-Oliveira JC, Angelini R, Isaac-Nahum VJ. Diet and niche breadth and overlap in fish communities within the area affected by an Amazonian reservoir (Amapá, Brazil). An Acad Bras Cienc 2014; 86(1): 383-405. http://dx.doi.org/10.1590/0001-3765201420130053. PMid:24676175.

Tavares-Dias M, Oliveira MSB, Gonçalves RA, Silva LMA. Ecology and seasonal variation of parasites in wild Aequidens tetramerus, a Cichlidae from the Amazon. Acta Parasito/ 2014; 59(1): 158-164. http://dx.doi.org/10.2478/s11686-014-0225-3. PMid:24570063.

Tavares-Dias M, Oliveira MSB. Structure of parasites community in Chaetobranchopsis orbicularis (Cichlidae), a host from the Amazon River system in northern Brazil. Parasitol Res 2017; 116(8): 2313-2319. http://dx.doi.org/10.1007/s00436-017-5539-2. PMid:28667520.

Thatcher VE. Amazon fish parasites. Sophia: Pensoft Publishers; 2006.

Torrente LJQG, Ohara VWM, Jansen THSP, Costa Doria ZCR. Peixes do Rio madeira. São Paulo: INPA; 2013.

Travassos L, Artigas P, Pereira C. Fauna helmintológica dos peixes de água doce do Brasil. Arq Inst Biol (Sao Paulo) $1928 ; 1$ : 5-82. Vazzoler A. Biologia da reprodução de peixes teleósteos: teoria e prática. Maringá: Eduem; 1996. 